Article

\title{
The immunomodulatory activity in vitro of NDV ZG1999HDS in comparison to NDV La Sota
}

\author{
Bratko Filipič ${ }^{*}$, Lidija Gradišnik ${ }^{2}$, Adriana Pereyra $^{3}$ and Hrvoje Mazija ${ }^{1}$
}

\begin{tabular}{l}
${ }^{1}$ CIETO (Croatian institute for experimental and translation oncology), Koledinečka 3, 10040 Zagreb, Croatia \\
Bratko.Filipic@gmail.com,$\underline{\text { Mazija@vef.unizg.hr }}$ \\
\hline${ }^{2}$ Institute of Biomedical Sciences, Medical Faculty, University of Maribor, Taborska 8, 2000 Maribor, Slovenia ; \\
lidija.gradisnik@UM.si \\
${ }^{3}$ MEDEX d.o.o., Linhartova cesta 49a, 1000 Ljubljana, Slovenia; adriana.pereyra@Medex.si \\
* Correspondence: Correspondence: Bratko.Filipic@gmail.com Mobile: 0038671232804
\end{tabular}

ABSTRACT. The immunotherapies, as a modern therapeutic approach, get an attention because of theirs' promise to treat a large number of different medical disorders. Immunomodulation effects of low titres (10 HA/ml) of NDV (Newcastle Disease Virus) ZG1999HDS or La Sota were tested on TLT (Human macrophage cell line) bound to PBMC (Peripheral Blood Mononuclear Cells). During the immunomodulation, the amount of $\mathrm{NO}, \mathrm{H}_{2} \mathrm{O}_{2}$, lysozym and induced antibacterial activity against Gram - positive bacteria (Staphylococcus aureus, MRSA, Streptococcus pyogenes, Streptococcus agalactiae and Streptococcus mutants) and against Gram - negative bacteria (Escherichia coli, Pseudomonas aeruginosa, Proteus mirabilis and Acinetobacter baumanii) were analysed. In addition, the cytokine secretion, IL-1 $\alpha$, IL-2, IL-4, GM-CSF, TNF- $\alpha$, IFN- $\alpha$ and IFN- $\alpha$ were evaluated. Firstly, the TLT cells are activated through the NDV ZG1999HDS or La Sota binding, followed by the NO "burst" and $\mathrm{H}_{2} \mathrm{O}_{2}$ and lysozyme level increase. Secondly, after the binding to the TLT cells and interaction with the PBMCs, the decrease of GM-CSF, and an increase of TNF $-\alpha$ and IFN $-\gamma$ were found. Simultaneously, the decrease of pro - inflammatory cytokine IFN- $\alpha$ and the differentially increase of IL- $1 \alpha$, IL-2 and IL-4 were recorded. During the induction of the antibacterial response, against Gram positive bacteria (Staphylococcus aureus, MRSA, Streptococcus pyogenes, Streptococcus agalactiae and Streptococcus mutants) the effect was one third higher with NDV ZG1999HDS compared to La Sota. Antibacterial response against Gram - negative bacteria (Escherichia coli, Pseudomonas aeruginosa, Proteus mirabilis and Acinetobacter baumanii) was not so clear. In general, NDV ZG1999HDS or La Sota activated TLT cells, further bound to PBMC; the ZG1999HDS is stronger immunomodulator than La Sota.

Keywords: Newcastle Disease Virus ZG1999HDS; Newcastle Disease Virus La Sota; immunomodulation; TLT (Human macrophage cell line) with PBMCs; Cytokines; lysozime; Antibacterial activity; Gram - positive bacteria; Gram - negative bacteria

\section{Introduction}

The substances interacting with the immune system with aim to increase or decrease the host response are named immunomodulators $[1,2,3]$. They are also known as biologic response modifier or immunoregulators, which function as a drug leading mostly to a non-specific stimulation of immunological defence mechanisms of the body [4,5]. To enhance immune system, the agents such as chemicals, proteins and/or viruses are used [6]. Among viruses, for the Newcastle Disease Virus (NDV) was found to have pleiotropic immunomodulatory properties in addition to good cell-binding and selective proliferation in replicating cells. Simultaneously this virus has the ability to introduce T-cell costimulatory activity and induce cytokines such as IFN- $\alpha$, IFN- $\beta$ and TNF- $\alpha$ that can affect T-cell recruitment and activation $[7,8,9]$. The cellular cytotoxicity of PBMC was enhanced 
significantly after the co-incubation of NDV with effector's cells [10, 11]. Through the study, the NK (natural killer) cells were found to be the main mediator of the cell lyses. The increased cytotoxicity also correlates with the induction of TNF- $\alpha$ and with the reduced synthesis of IFN- $\alpha$ in PBMC by NDV. The strain of NDV, ZG1999HDS that was recently isolated, was patented and genetically characterized by Mazija [12, 13] and by Nedeljković [14]. Additionally, the strain of NDV ZG1999HDS was deposited in "Collection National de Cultures de Microorganisms (CNCM)" in the year 2013 [15] and in the "Gene Bank" at 2014 [16]. The strain of NDV ZG1999HDS was isolated only from lung tissue of broiler chickens suffering of a respiratory disease and was not present in the brain tissue, as it was described by Biđin and Mazija [17]. Due to its lentogenic properties that it caused death of $74.6 \%$ of chickens because of the virus tropism for the respiratory system. It belongs to genotype II of class II NDV that is closely related to the strains of NDV La Sota and Hitcher. In the same group, there are strains: La Sota, Ulster and Queensland. Cytolytic characteristics of the strain of NDV ZG1999HDS were investigated in vitro on tumour cell cultures and in vivo on mice's and compared with the impact of the strain of NDV La Sota. The strain of NDV ZG1999HDS is a relatively strong inducer of human type I IFN, more precisely HuIFN- $\alpha \mathrm{N} 3$, in the PBMCs from Human Buffy coats. $100 \mathrm{HA}$ of the strain of NDV ZG1999HDS can induce $483 \pm 45 \mathrm{pg} / \mathrm{ml}$ of the HuIFN- $\alpha$ N3. The RP-HPLC profile of the HuIFN- $\alpha \mathrm{N} 3$ show: subtypes $\alpha 1, \alpha 2, \alpha \mathrm{A}$ and $\alpha 2 \mathrm{~b}$. [18] For the biological activity of the NDV induced HuIFN- $\alpha$ N3, it is important the relative ratio between the $\alpha 1$ and $\alpha 2$ subtypes [19].

The presented experiments were aimed to analyse the immunomodulatory activity in vitro of the strain of NDV ZG1999HDS in comparison to the strain of NDV La Sota.

\section{Material and methods}

\subsection{Viruses used in the experiments}

The strain of NDV ZG1999HDS virus was obtained from theProf. emeritus Hrvoje Mazija (Croatian institute for experimental and translation oncology, Koledinečka 03, 10040 Zagreb, Croatia). The strain of NDV La Sota vas obtained from different commercial sources. Both of them were multiplied in SPF (Specific Pathogen Free) chicken embryos, and concentrated by lyophilisation. The EID 50 that was determined in the SPF chicken em-

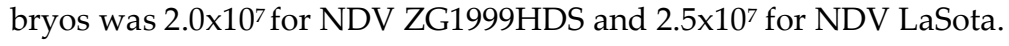

\subsection{Tissue culture medium and cells}

Eagle's medium with high content of glucose, L-glutamine, $25 \mathrm{mM}$ HEPES and antibiotics (Penicillin, Streptomycin and Gentamycin) and Trypsin solution were prepared in the CIETO laboratory. FBS (Foetal bovine serum) was from Euro clone (Pero, Italy). Human TLT (macrophage) cell line was obtained from As. Mag. Lidija Gradišnik from the Institute of Biomedical Sciences, Medical Faculty in Maribor, University of Maribor, Slovenia. The TLT cells were cultivated in Eagle's medium with a high content of glucose, L-glutamine, 25mM HEPES and antibiotics with the addition of $10 \%$ of FBS.

\subsection{Isolation of PBMC (Peripheral Blood Mononuclear Cells) from Human Buffy coats}

The Buffy coats were combined and centrifuged at $1700 \mathrm{RPM}$ for $20 \mathrm{~min}$ at $4^{\circ} \mathrm{C}$. The supernatant containing plasma and part of the leukocytes were resuspended in the PBS containing $1 \%$ of glucose. To the sediment containing erythrocytes, lymphocytes, macrophages and granulocytes, the nine parts of $0.83 \% \mathrm{NH}_{4} \mathrm{Cl}$ (ammonium chloride) were added. The erythrocyte lyses was performed at $4^{\circ} \mathrm{C}$ during $15-20 \mathrm{~min}$. After this, cell suspension of "black chocolate colour" was centrifuged at 2,500 RPM for 20 minutes at $4^{\circ} \mathrm{C}$. The supernatant was removed and the white cell sediments were resuspended in the PBS (Phosphate Buffer Saline) containing 1\% of glucose. Both supernatants were combined and white cells were sediment by centrifugation at $2500 \mathrm{RPM}$ for $20 \mathrm{~min}$ at $4^{\circ} \mathrm{C}$. The percentage of living cells was determined by Trypan blue staining. 


\subsection{Bacterial species used in the experiments}

Bacterial species selected for the study, were obtained from the "Microbecollection" at the Institute for Microbiology and Immunology, Medical Faculty,University of Ljubljana, Slovenia. The Gram - positive bacteria were: Staphylococcus aureus, MRSA (Metycilline Resistant Staphylococcus aureus), Micrococcus luteus, Streptococcus pyogenes, Streptococcus agalactiae and Streptococcus mutants. Gram -negative bacteria were: Escherichia coli, Pseudomonas aeruginosa, Proteus mirabilis and Acinetobacter baumanii.

\subsection{Cells' treatment}

In the $10.0 \mathrm{ml}$ flat bottom glass vials with rubber stoppers, the Human macro-phage (TLT) cell line was cultivated in the Eagle's medium with $10 \%$ of FBS. After reaching the confluence, the supernatant was discharged and the $2.0 \mathrm{ml}$ of PBMC suspension (106 cells $/ \mathrm{ml}$ ) was added. After two hours, $2.5 \mathrm{ml}$ of Eagle's medium with $2.0 \%$ of FBS was added. To exert the immunomodulation and the antimicrobial activity, $0.5 \mathrm{ml}$ of 10.0 $\mathrm{HAU} / \mathrm{ml}$ of the strain of NDV ZG1999HDS or La Sota were added and vials were stored at $37^{\circ} \mathrm{C}$ for 24 and 48 hours (Figure 1). All the treatments were performed in triplicate and repeated two to three times. After the indicated time ( 24 or 48 hours at $37{ }^{\circ} \mathrm{C}$ ) the vials were centrifuged at $1700 \mathrm{RPM} / 20$ minutes, and clear supernatants were collected, filtered through $0.2 \mu \mathrm{m}$ filters and stored before the analyses at $-20^{\circ} \mathrm{C}$.

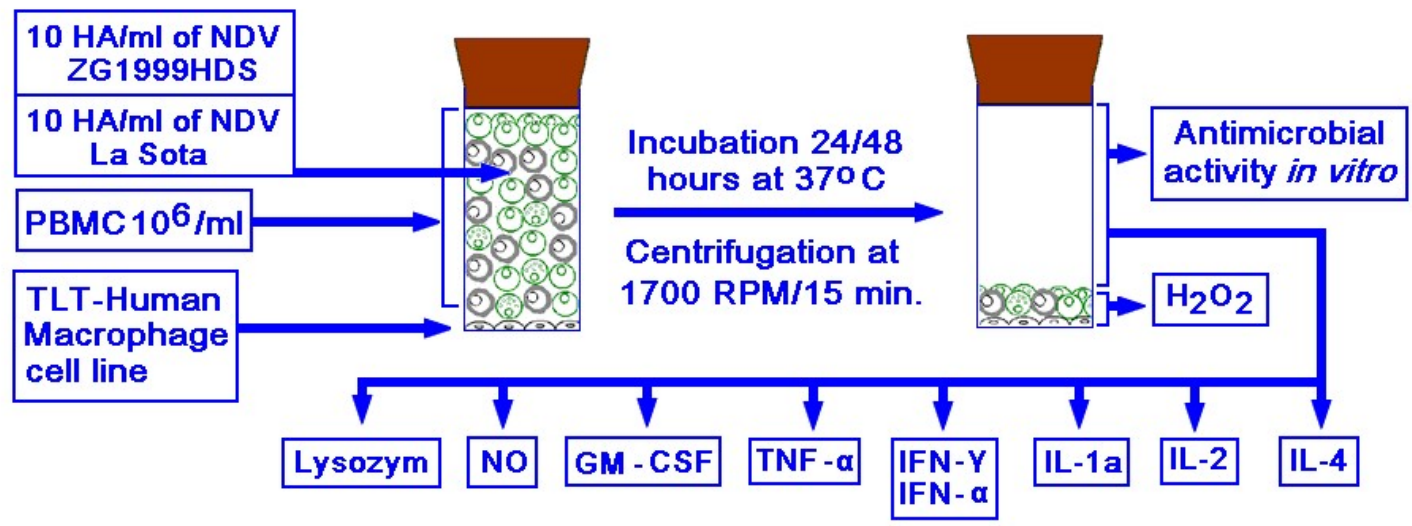

Figure 1. The immunomdulatory activity of $10 \mathrm{HA} / \mathrm{ml}$ of the strain of NDV ZG1999HDS or 10HA/ml of the strain NDV La Sota on the activation of TLT cells cultivated with the Human PMBCs.

\subsection{The $\mathrm{H}_{2} \mathrm{O}_{2}$ (Hydrogen peroxide) determination}

Quantity $(\mu \mathrm{M} / \mathrm{ml})$ of $\mathrm{H}_{2} \mathrm{O}_{2}$ produced by the cultivated cells (TLT with PBMC) after the treatment or in untreated control was determined according to the method developed by Orsi et al. [20]. In brief: To the freshly sediment of cells (TLT with PBMC) $500.0 \mu \mathrm{l}$ of the Phenol red solution $\left(50 \mathrm{ml}\right.$ ) containing $140.0 \mathrm{mM} \mathrm{NaCl}, 10.0 \mathrm{mM} \mathrm{K}_{2} \mathrm{HPO}_{4}$, $5.5 \mathrm{mM}$ dextrose and $8.5 \mathrm{U} / \mathrm{ml}$ of Horseradish peroxidase. After four hours of incubation at $37^{\circ} \mathrm{C}, 100.0 \mu \mathrm{l}$ of $1.0 \mathrm{M} \mathrm{NaOH}$ was added, and solution was dissolved for 10 times with $4.5 \mathrm{ml}$ of saline. The optical density of the solution was measured at $620.0 \mathrm{~nm}$. As the control, $10.0 \mathrm{mM}$ of $\mathrm{H}_{2} \mathrm{O}_{2}$ was used.

\subsection{Lysozym determination}

The amount of lysozym in the cells' (TLT with PMBC) supernatant was determined according to the method developed by Nash et al. [21]. In brief: one thousand CFU (Colony Forming Units) of Streptococcus pyogenes in $200.0 \mu \mathrm{l}$ of $10.0 \mathrm{mM}$ PBS (Potassium phosphate 
buffer) (pH 7.4) and $200.0 \mu \mathrm{l}$ of sample or 1.0, 10.0 and $100.0 \mu \mathrm{g} / \mathrm{ml}$ of lysozyme were added to the $1.6 \mathrm{ml}$ of $\mathrm{MH}$ (Mueller Hinton) - broth ( $\mathrm{pH}$ 6.5) and incubated overnight at $37{ }^{\circ} \mathrm{C}$. On the next day, the OD was measured at $595 \mathrm{~nm}$. The amount of lysozyme $(\mu \mathrm{M} / \mathrm{ml})$ was calculated in comparison to the bacterial OD after 24 hours.

\subsection{The NO (Nitrite) assay}

The concentration of stable NO (nitrite), that is an end product of the nitric oxide present in the supernatant of treated or untreated human macrophages (TLT with $\mathrm{PMBC}$ ) was measured by the method based on the Griess reaction, that was described by More and Pai [22]. In brief, $50 \mu 1$ of the cells' supernatant was incubated with the equal volume of Griess reagent composed from $1 \%$ of sulphanilamide in 2,5\% $\mathrm{H}_{3} \mathrm{PO}_{4}$ and $0,1 \%$ of NEDD (naphytyl-ethylene-diamine-dihydrochloride) in distilled water. Both solutions were mixed in a ratio of 1:1 at room temperature for 30 minutes. The absorbance at $550 \mathrm{~nm}$ was measured in a micro titre plate reader. The standard curve for nitrite was prepared using 10 $100 \mu \mathrm{M}$ sodium nitrites in distilled water.

\subsection{HuIFN- $\alpha$ N3 monoclonal ELISA}

The quantity of induced HuIFN- $\alpha \mathrm{N} 3(\mathrm{pg} / \mathrm{ml})$ was determined by Human IFN

ELISA kit »Platinum ELISA« from eBioscience (Vienna, Austria). In the assay, the international HuIFN- $\alpha \mathrm{N} 3$ standard was used (Human IFN- $\alpha$ Platinum ELISA (BMS 216/BMS 216 TEN), Affymetrix, eBioscience, USA). The assay was performed according to the manufacturer's instructions, with the final reading by the ELISA reader at $620 \mathrm{~nm}$ and calculating of the pg-s of HuIFN- $\alpha \mathrm{N} 3 / \mathrm{ml}$.

\subsection{HuIFN- $\alpha$ N3 RP-HPLC analysis}

The HuIFN- $\alpha$ N3 subtype composition was analyzed by the RP - HPLC (Reverse phase high performance liquid chromatography). Different HuIFN- $\alpha$ samples (natural or recombinant, approximately one million antiviral units $/ \mathrm{ml}$ ) of 20 to $40 \mu \mathrm{l}$ were applied to the Phenomenex, Aeris PEPTIDE column 3.6 $\mathrm{m}$ XB-C18, $250 \times 4.6 \mathrm{~mm}$ and eluted with the linear gradient of solvent $\mathrm{A}=$ water $+0.1 \%$ of TFA and solvent $\mathrm{C}=$ acetonitril $+0.1 \%$ TFA for 20 minutes with a flow rate of $0.8 \mathrm{ml} / \mathrm{min}$. and pressure of $139-140 \mathrm{bar}$. The course of RP-HPLC chromatography of different IFN samples is shown in Table 1 . The temperature of the column was $40^{\circ} \mathrm{C}$. The absorbance was monitored at 214 and $280 \mathrm{~nm}$. HuIFN- $\alpha$ interferon species in different IFN compositions were separated according to theirs relative hydrophobic using RP-HPLC as it was described by Punainen et al.[23].

Table 1. The course of RP-HPLC chromatography of different IFN samples.

\begin{tabular}{cccc}
\hline Step: & Time (min.): & Solvent A (\%) & Solvent C (\%) \\
\hline 0 & 0 & 91 & 9 \\
\hline 1 & 3 & 80 & 20 \\
\hline 2 & 6 & 50 & 50 \\
\hline 3 & 12 & 50 & 50 \\
\hline 4 & 15 & 91 & 9 \\
\hline 5 & 20 & 91 & 9 \\
\hline
\end{tabular}

2.11. HuIFN- $\gamma$ Mini ELISA Development Kit (Peprotech) 
The amount of HuIFN- $\gamma(\mathrm{pg} / \mathrm{ml})$ in the cell (TLT with PBMC) supernatantwas performed according to the manufacturer instructions. Bind the capture antibodies $(1.0 \mu \mathrm{g} / \mathrm{ml})$ to the Nunc Maxisorp plates, and add the $300.0 \mu \mathrm{l}$ of the blocking buffer.

Standard/Sample: Dilute standard (HuIFN- $\gamma$ ) from $300.0 \mathrm{pg} / \mathrm{ml}$ to zero in diluents. Immediately add $100.0 \mu \mathrm{l}$ of standard or sample to each well in triplicate and incubate the plates for six hours at $37^{\circ} \mathrm{C}$.

Detection: After washing the plates, dilute the detection antibodies in diluent to a concentration of $1.0 \mu \mathrm{g} / \mathrm{ml}$ and add $100.0 \mu \mathrm{l} /$ well and incubate at room temperature for two hours.

Avidin-HRP Conjugate: After washing the plates, dilute $5.5 \mu \mathrm{l}$ of Avidin-HRP Conjugate 1:2000 in diluent for total volume of $11.0 \mathrm{ml}$. Add $100 \mu \mathrm{l} /$ well. Incubate plates one hour at room temperature.

ABTS Liquid Substrate: Wash and aspirate the plates two times. To the empty plates add $100.0 \mu \mathrm{l}$ of substrate solution to each well and monitor the colour development. After, add $10.0 \mu \mathrm{l}$ of $1.0 \%$ SDS to each well and measure the plate with the ELISA reader at 405 $\mathrm{nm}$ with the wavelength correction at $650 \mathrm{~nm}$. The reliable standard curves are obtained when either OD readings should not exceed 0.2 units for the zero standard concentration, or 1.2 units for the highest standard.

\subsection{GM-CSF Mini ELISA Development Kit (Peprotech)}

The amount of GM - CSF (pg/ml) in the cell (TLT with PBMC) supernatant was performed in the same way as in the case of HuIFN- $\gamma$, with the use of GM - CSF specific capture and detection antibodies as well as specific Avidin-HRP (Horse-radish Peroxidase) conjugate.

\subsection{TNF- $\alpha$ Mini ELISA Development Kit (Peprotech)}

The amount of TNF- $\alpha(\mathrm{pg} / \mathrm{ml})$ in the cell (TLT with PBMC) supernatant was performed in the same way as in the case of HuIFN- $\gamma$, with the use of TNF- $\alpha$ specific capture and detection antibodies as well as specific avidin-HRP (Horse-radish Peroxidase) conjugate.

\subsection{IL-1 $\alpha$ Mini ELISA Development Kit (Peprotech)}

The amount of IL-1 $\alpha$ (pg/ml) in the cell (TLT with PBMC) supernatant was performed in the same way as in the case of HuIFN- $\gamma$, with the use of IL- $1 \alpha$ specific capture and detection antibodies as well as specific avidin-HRP (Horse-radish Peroxidase) conjugate.

\subsection{IL-2 Mini ELISA Development Kit (Peprotech)}

The amount of IL-2 (pg/ml) in the cell (TLT with PBMC) supernatant was performed in the same way as in the case of HuIFN- $\gamma$, with the use of IL-2 specific capture and detection antibodies as well as specific avidin-HRP (Horse-radish Peroxidase) conjugate.

\subsection{IL-4 Mini ELISA Development Kit (Peprotech)}

The amount of IL-4 (pg/ml) in the cell (TLT with PBMC) supernatant was performed in the same way as in the case of HuIFN- $\gamma$, with the use of IL- 4 specific capture and detection antibodies as well as specific avidin-HRP (Horse-radish Peroxidase) conjugate.

\subsection{Antibacterial activity}

The antibacterial (Gram - positive and Gram - negative bacteria) screening was carried out by agar diffusion method described by Lino and Deogracious [24]. According to theirs' protocols the suspensions of different bacteria in saline with McFarland 0, 5 were swabbed over the surface of the MH (Mueller Hinton) agar plate, using a sterile cotton swab. Wells of $6.0 \mathrm{~mm}$ diameter were bored in the medium with the help of a sterile corkborer, having a $6.0 \mathrm{~mm}$ diameter. $70 \mu \mathrm{l}$ of different samples were filled in the wells with a micropipette. On separate plate $70 \mu \mathrm{l}$ of the control antibiotics in a concentration of $10 \%$ 
were added. The plates were left for some time till the extracts diffused into the medium, with the lid closed, and incubated at $37^{\circ} \mathrm{C}$ for 72 hours. The zone of the inhibition was measured in millimetres using a scale.

\subsection{Statistics}

All the treatments were performed in triplicate and repeated three to fourtimes. The average values \pm SD (Standard deviation) were recorded. The obtained data were analyzed by the Two-tailed unpaired student's $t$ test for the groups comparing NDV1999HDS to La Sota group. The Stat graphics stratus online statistics software (www.statgraphicsstratus.com) from Stat point Technologies Inc., USA was used. Statistically significant were differences with the $\mathrm{p}$ values: ${ }^{*}=<0.05,{ }^{* *}=<0.01$.

\section{Results}

\subsection{Determining of $\mathrm{NO}$ (Nitric oxide), $\mathrm{H}_{2} \mathrm{O}_{2}$ (Hydrogen peroxide) and lysozym}

In case of $\mathrm{NO}$, the releasing enhancement was found $(7.12 \mu \mathrm{M} / \mathrm{ml})$ when NDV ZG1999HDS was used. The level of $\mathrm{H}_{2} \mathrm{O}_{2}$ and lysozyme were increased with the use of the same virus $(1.82 \mu \mathrm{M}$ and $0.748 \mu \mathrm{g})$. The lysozym is the indicator of the antimicrobial activity induction. The results are presented in the Figure 2 and Table 2.

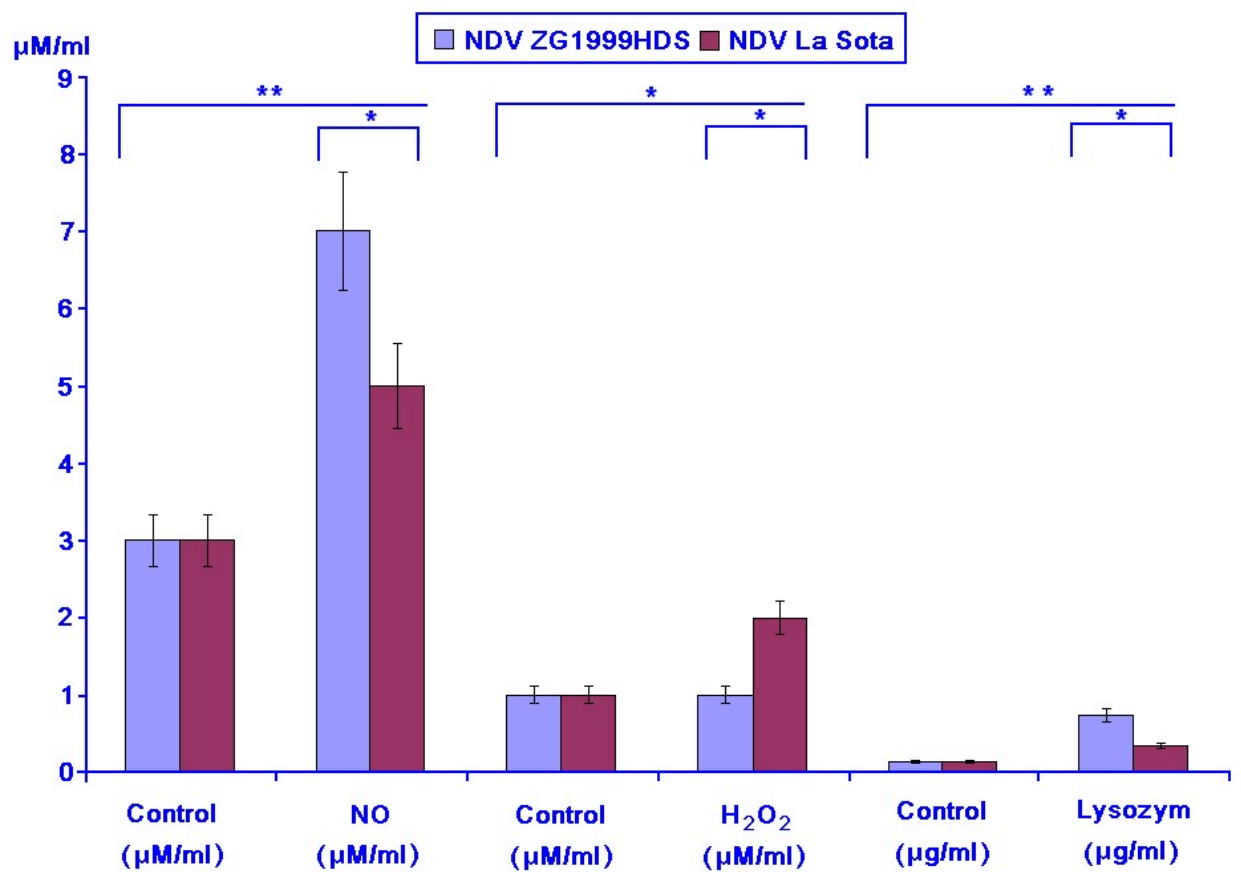

Significant differences with the p values: $*=<0.05 * \star=<0.01$

Figure 2. The influence of the strain of NDV ZG1999HDS or strain of NDV La Sota on the level of $\mathrm{NO}_{2} \mathrm{H}_{2} \mathrm{O}_{2}$ and lysozym released from activated TLT cells cultivated with human PBMCs.

Table 2. Influence of NDV strain ZG1999HDS or NDV strain La Sota on the $\mathrm{NO}, \mathrm{H}_{2} \mathrm{O}_{2}$ and Lysozym level.

\begin{tabular}{ccccccc}
\hline Virus & \multicolumn{2}{c}{$\mathrm{NO}(\mu \mathrm{M} / \mathrm{ml})$} & \multicolumn{2}{c}{ H2O2 $(\mu \mathrm{M} / \mathbf{m l})$} & \multicolumn{2}{c}{ Lysozym $(\mu \mathrm{M} / \mathbf{m l})$} \\
\hline & Control & NO & Control & $\mathbf{H}_{2} \mathbf{O}_{2}$ & Control & Lysozym \\
\hline NDV ZG1999HDS & $3 \pm 0.66$ & $7 \pm 1,12$ & $1 \pm 0.17$ & $1 \pm 0.082$ & $0.14 \pm 0.05$ & $0.74 \pm 0.08$ \\
\hline NDV La Sota & $3 \pm 0.66$ & $5 \pm 0.86$ & $1 \pm 0.17$ & $2 \pm 0.065$ & $0.14 \pm 0.05$ & $0.34 \pm 0.05$ \\
\hline
\end{tabular}


GM-CSF as proliferators of different tumour cells in vitro and in vivo was inhibited by either NDV ZG1999HDS or NDV La Sota. The opponent TNF- $\alpha$ was increased, when the NDV ZG1999HDS was used. In case of NDV La Sota the level of TNF $-\alpha$ was decreased. In Table 3 and Figure 3, there are the data about GM-CSF and TNF- $\alpha$ analysis.

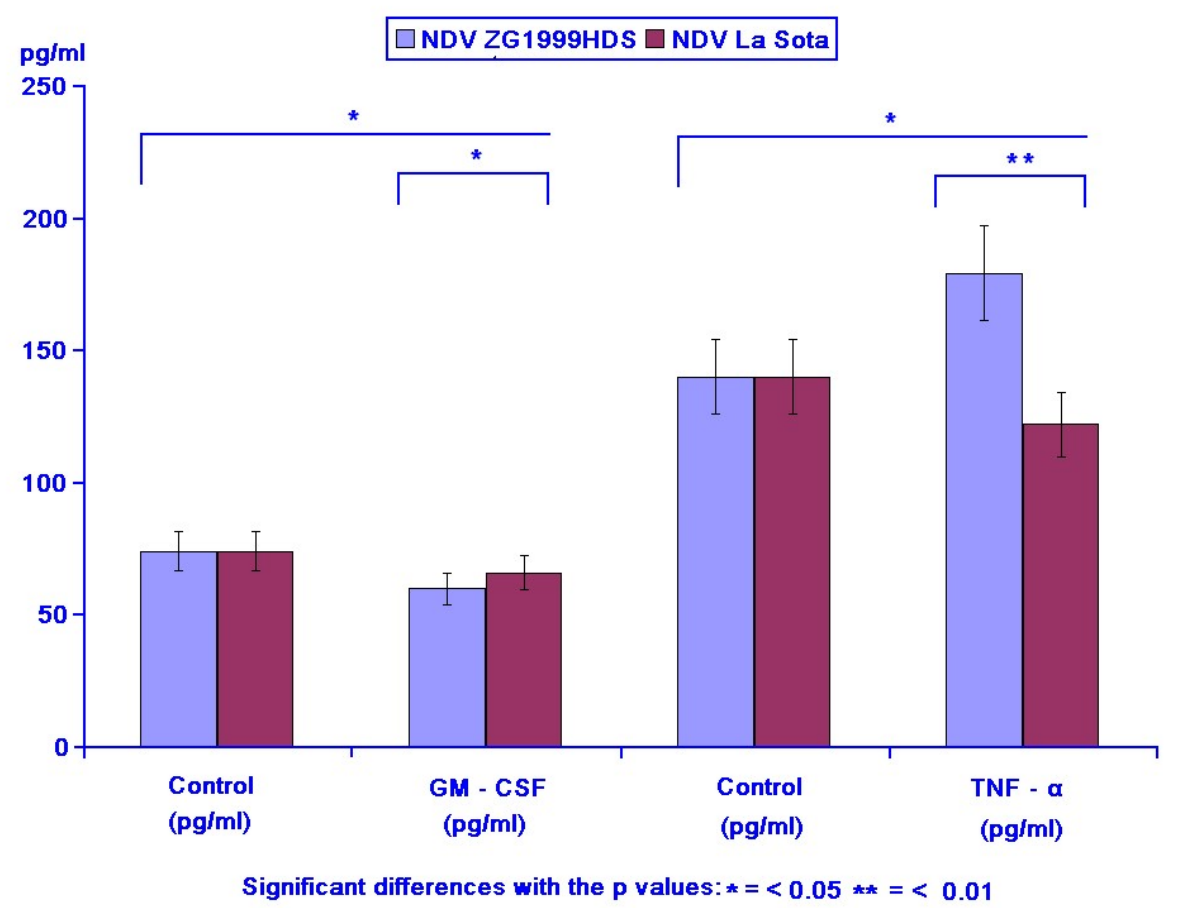

Figure 3. The influence of the strain of NDV ZG1999HDS or strain of NDV La Sota on the level of GM - CSF and TNF - $\alpha$ released from activated TLT cells cultivated with human PBMCs.

Table 3. Influence of NDV strain ZG1999HDS or NDV strain La Sota on the level of GM-CSF and TNF- $\alpha$.

\begin{tabular}{ccccc}
\hline Virus & \multicolumn{2}{c}{ GM-CSF (pg/ml) } & \multicolumn{2}{c}{ TNF- $\boldsymbol{\alpha}(\mathbf{p g} / \mathbf{m l})$} \\
\hline & Control & GM-CSF & Control & TNF- $\alpha$ \\
\hline NDV ZG1999HDS & $74 \pm 4.21$ & $63 \pm 4.10$ & $140 \pm 22$ & $179 \pm 34$ \\
\hline NDV La Sota & $74 \pm 4.21$ & $66 \pm 4.25$ & $140 \pm 22$ & $122 \pm 18$ \\
\hline
\end{tabular}

\subsection{Activity of IFN- $\gamma$ and IFN- $\alpha$}

When the levels of two different IFNs were studied, the following data were obtained: Increase of IFN- $\gamma$ and decrease of pro-inflammatory IFN- $\alpha$. The higher increase of HuIFN- $\gamma$ was found with NDV ZG1999HDS and higher decrease of HuIFN- $\alpha$. Data about level of IFN- $\alpha$ and IFN- $\gamma$ are shown in Table 4 and Figure 4 . The RP-HPLC profile of NDV ZG1999HDS induced interferon's show the higher decrease of $\alpha 2, \alpha \mathrm{A}$ and $\alpha 1$ and total absence of $\alpha 2 b$ together with the increase of the HuIFN- $\gamma$ in comparison to the NDV La Sota induced interferon's (Figure 5). 


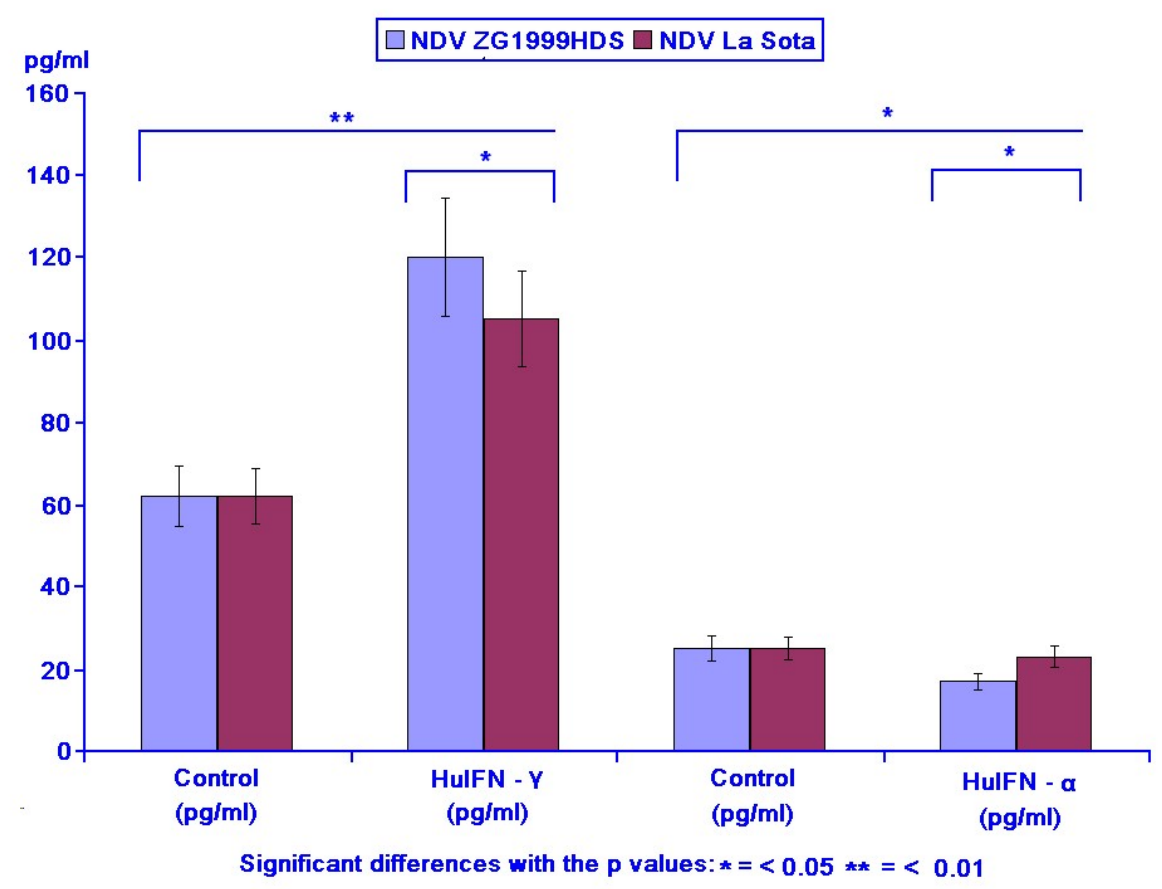

Figure 4. The influence of NDV strain ZG1999HDS or NDV strain La Sota on the level of HuIFN- $\gamma$ and HuIFN- $\alpha$ released from activated TLT cells cultivated with PBMCs.

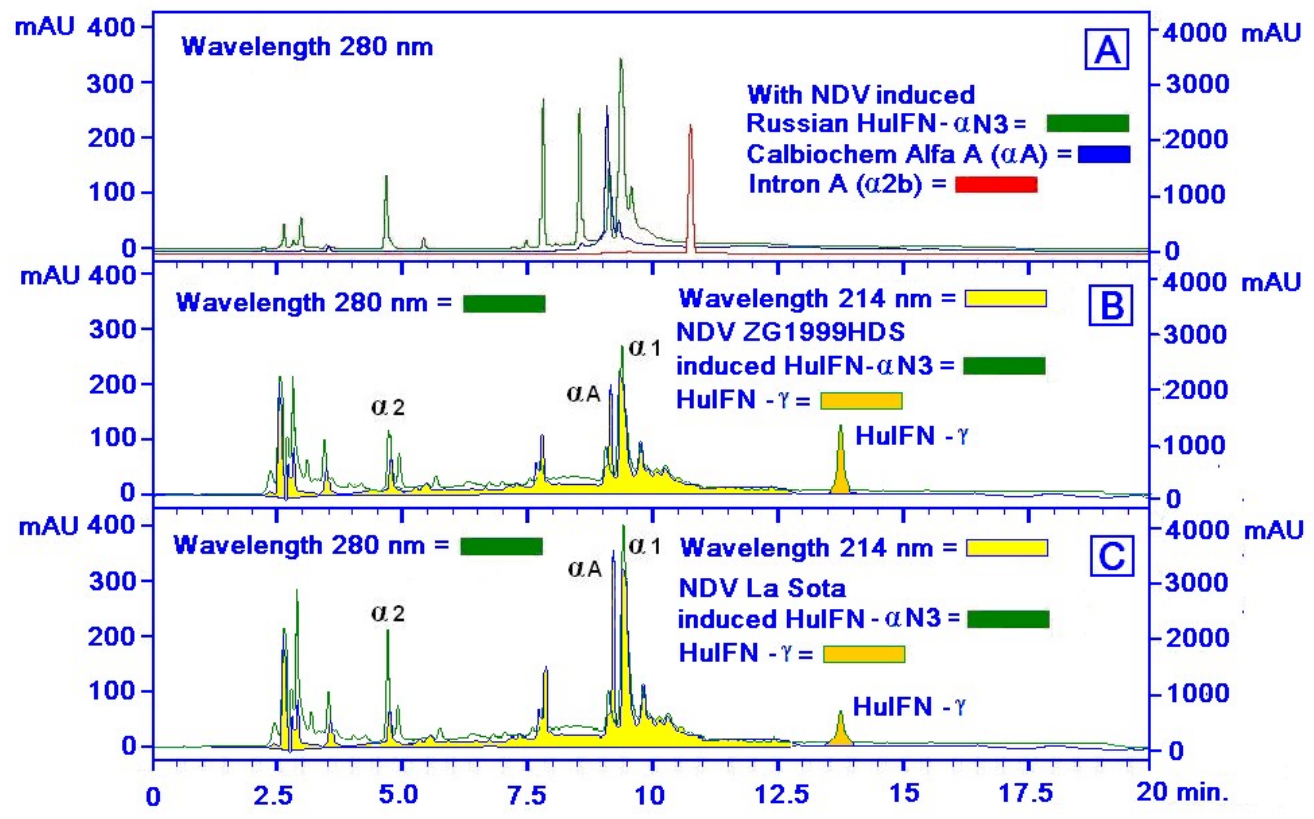

Figure 5. The RP-HPLC profiles of NDV ZG1999HDS or NDV La Sota induced Interferons.(A) With the NDV induced Russian HuIFN- $\alpha$ N3; (B) With NDV ZG1999HDS induced HuIFN- $\alpha$ N3 and HuIFN- $\gamma$; (C) With NDV La Sota induced HuIFN- $\alpha \mathrm{N} 3$ and HuIFN- $\gamma$. 
Table 4. Influence of NDV strain ZG1999HDS or NDV strain La Sota on the level of HuIFN- $\gamma$ and HuIFN- $\alpha$.

\begin{tabular}{ccccc}
\hline Virus & \multicolumn{2}{c}{ HuIFN- $\gamma(\mathrm{pg} / \mathrm{ml})$} & \multicolumn{2}{c}{ HuIFN- $\alpha(\mathrm{pg} / \mathrm{ml})$} \\
\hline & Control & HuIFN- $\gamma$ & Control & HuIFN- $\alpha$ \\
\hline NDV ZG1999HDS & $62 \pm 3.10$ & $120 \pm 9.88$ & $25 \pm 1.39$ & $19 \pm 1.22$ \\
\hline NDV La Sota & $62 \pm 3.10$ & $105 \pm 7.35$ & $25 \pm 1.39$ & $23 \pm 1.98$ \\
\hline
\end{tabular}

\subsection{Activity of $I L-1 \alpha, I L-2$ and $I L-4$}

The level of IL-1 $\alpha$ being the cytokine inducing the "Programmed cell death « (apoptosis) of mostly different tumour cells was increased, similarly as IL-2 and IL-4 when NDV (strain ZG1999HDS) was used (Table 5, Figure 6).

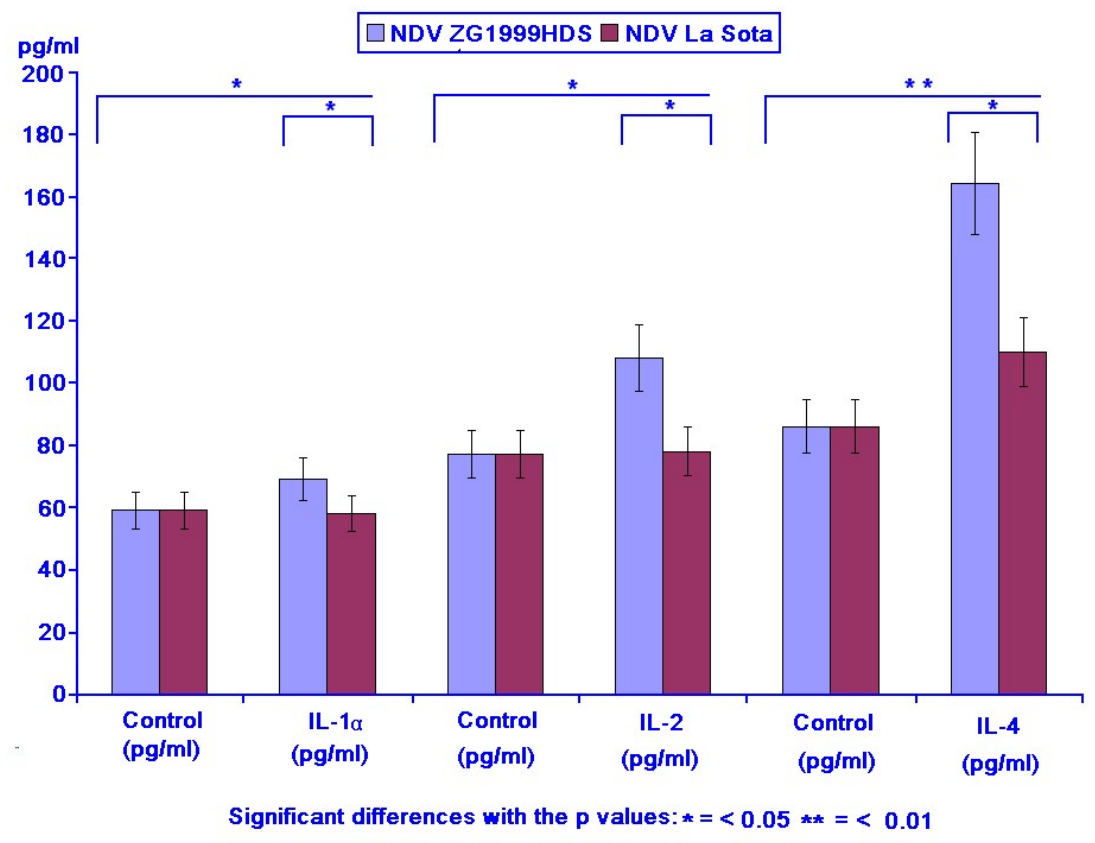

Figure 6. The influence of NDV ZG1999HDS or NDV La Sota on the level of IL-1 $\alpha$, IL-2 and IL-4 released from activated TLT(Human macrophage cell line) +PBMCs.

Table 5. Influence of NDV strain ZG1999HDS or NDV strain La Sota on the level of IL-1 $\alpha$, IL-2 and IL-4.

\begin{tabular}{ccccccc}
\hline Virus & IL-1 $\alpha$ & $\mathbf{( p g / m l )}$ & \multicolumn{2}{c}{ IL-2 $(\mathbf{p g} / \mathbf{m l})$} & \multicolumn{2}{c}{ IL-4 (pg/ml) } \\
\hline & Control & IL-1 $\alpha$ & Control & IL-2 & Control & IL-4 \\
\hline NDV ZG1999HDS & $59 \pm 6.33$ & $68 \pm 2.11$ & $77 \pm 4.17$ & $108 \pm 8.42$ & $86 \pm 9.13$ & $164 \pm 6.11$ \\
\hline NDV La Sota & $59 \pm 6.33$ & $62 \pm 1.86$ & $77 \pm 4.17$ & $79 \pm 6.15$ & $86 \pm 9.13$ & $110 \pm 5.14$ \\
\hline
\end{tabular}

\subsection{Antibacterial activity}

Concomitantly with the immunomodulation, the induced antibacterial activity against different Gram - positive and Gram-negative bacteria was studied. The induced antibacterial activity was compared with the NDV La Sota. In general, it can be concluded, that NDV ZG1999HDS induced higher antibacterial activity against Gram - positive 
bacteria, than against Gram - negative one. It seems that such activity could be connected to the lysozime content. (Table 6 Figure 7 and Figure 8 )

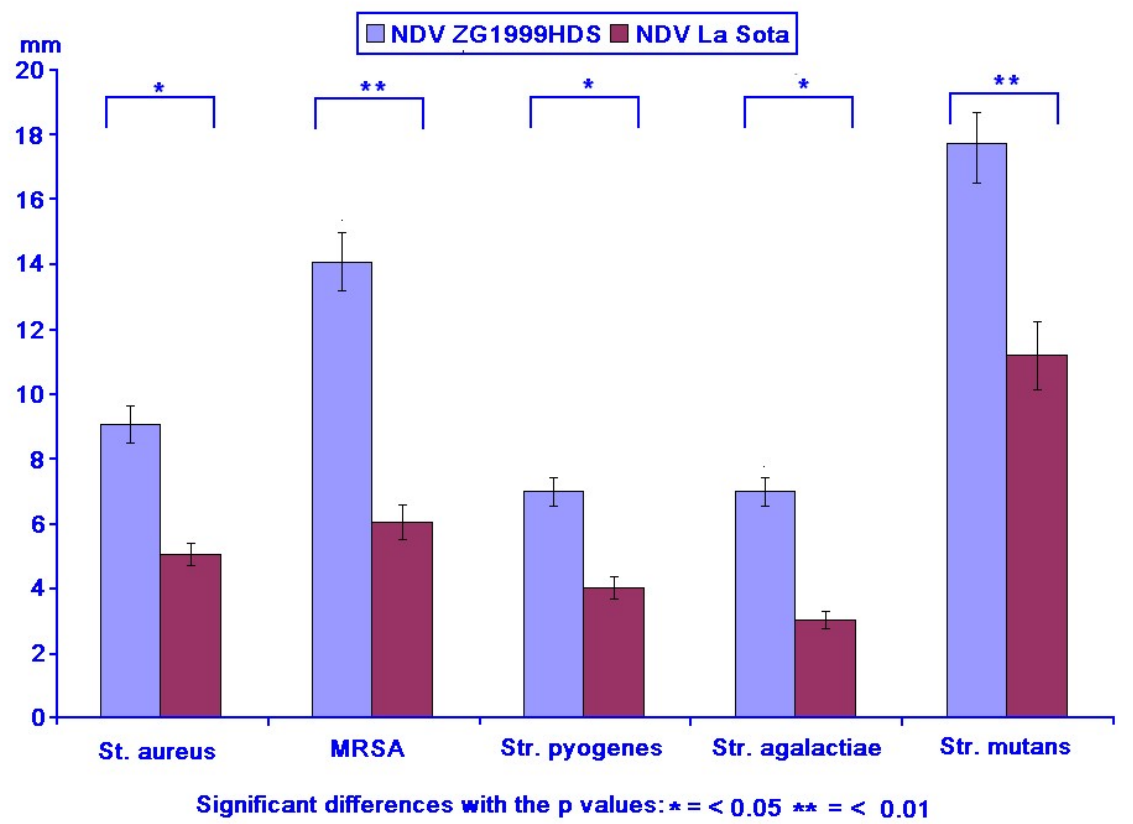

Figure 7. Induction of antibacterial activity against different Gram - positive bacteria with the strain of. NDV ZG1999HDS or of the strain of NDV La Sota.

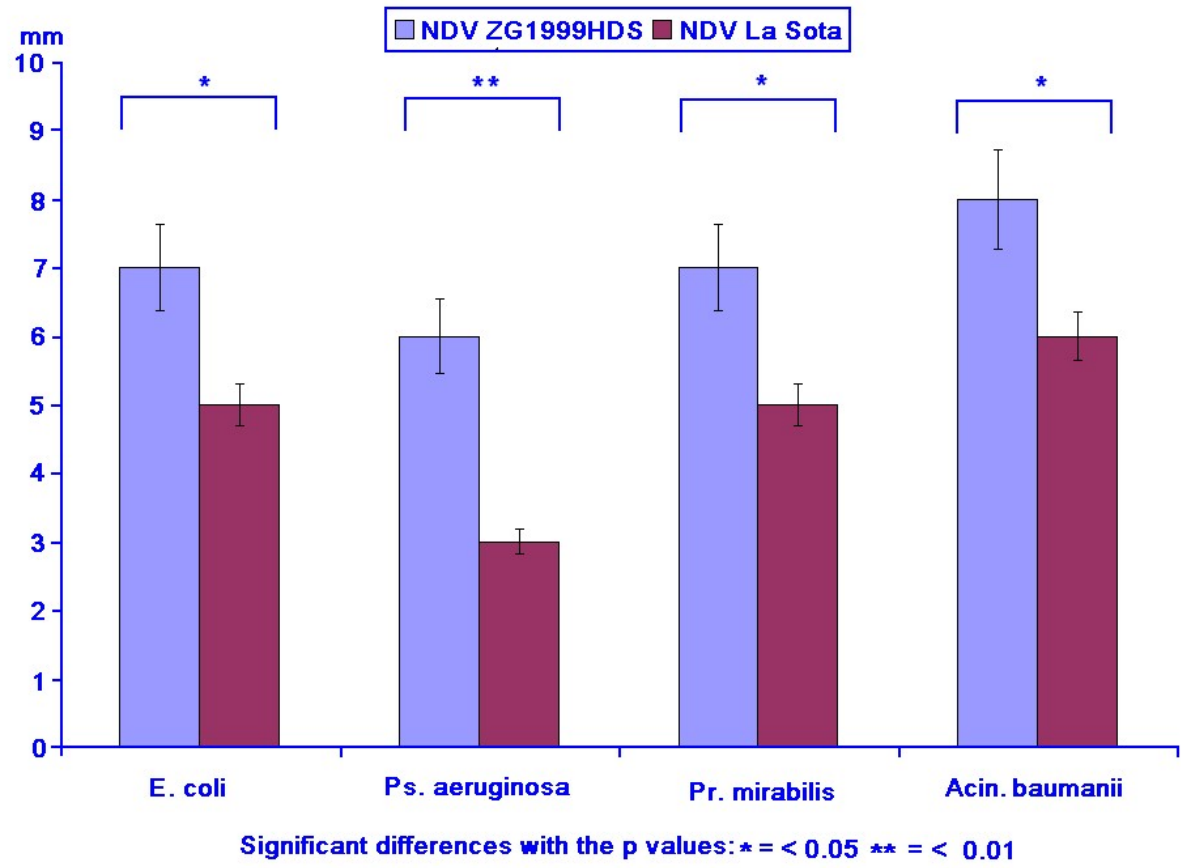

Figure 8. Induction of antibacterial activity against different Gram - negative bacteria with NDV ZG1999HDS and NDV La Sota.

Table 6. By NDV strain ZG1999HDS or NDV strain La Sota induced antibacterial activity against various Gram - positive and Gram - negative bacteria. 


\begin{tabular}{|c|c|c|c|c|c|}
\hline Gram - positive bacteria & $\begin{array}{c}\text { NDV } \\
\text { ZG1999HDS } \\
(\mathrm{mm})\end{array}$ & $\begin{array}{l}\text { NDV } \\
\text { La Sota } \\
\text { (mm) }\end{array}$ & $\begin{array}{l}\text { Penicillin } \\
\quad(\mathrm{mm})\end{array}$ & $\begin{array}{l}\text { Streptomycin } \\
(\mathrm{mm})\end{array}$ & $\begin{array}{c}\text { Gentamycin } \\
(\mathrm{mm})\end{array}$ \\
\hline Staphylococcus aureus & $9.0 \pm 1.6$ & $4.0 \pm 0.5$ & $8.0 \pm 1.3$ & $6.0 \pm 0.3$ & $8.0 \pm 1.3$ \\
\hline$M R S A^{11}$ & $14.0 \pm 2.5$ & $6.0 \pm 0.3$ & $4.0 \pm 0.5$ & $3.0 \pm 0.3$ & $13.0 \pm 2.5$ \\
\hline Streptococcus pyogenes & $7.0 \pm 1.4$ & $4.0 \pm 0.5$ & $12.0 \pm 2.5$ & $14.0 \pm 2.5$ & $18.0 \pm 3.2$ \\
\hline Streptococcus agalactiae & $7.0 \pm 1.4$ & $3.0 \pm 0.3$ & $8.0 \pm 1.3$ & $16.0 \pm 2.5$ & $14.0 \pm 2.5$ \\
\hline Streptococcus mutants & $19.0 \pm 2.5$ & $13.0 \pm 2.5$ & $6.0 \pm 0.3$ & $12.0 \pm 2.5$ & $14.0 \pm 2.5$ \\
\hline \multicolumn{6}{|l|}{ Gram - negative bacteria } \\
\hline Escherichia coli & $7.0 \pm 1.3$ & $5.0 \pm 0.5$ & $8.0 \pm 1.3$ & $14.0 \pm 2.5$ & $18.0 \pm 2.5$ \\
\hline Pseudomonas aeruginosa & $6.0 \pm 0.5$ & $3.0 \pm 0.3$ & $4.0 \pm 0.3$ & $7.0 \pm 1.3$ & $8.0 \pm 1.3$ \\
\hline Proteus mirabilis & $7.0 \pm 0.5$ & $6.0 \pm 0.5$ & $5.0 \pm 0.5$ & $9.0 \pm 1.3$ & $8.0 \pm 1.3$ \\
\hline Acinetobacter baumanii & $8.0 \pm 0.7$ & $6.0 \pm 0.5$ & $3.0 \pm 0.3$ & $18.0 \pm 2.5$ & $16.0 \pm 2.5$ \\
\hline
\end{tabular}

\section{Discussion}

The results of the experiments, comparing the immunomodulatory activity of low amount $(10 \mathrm{HA} / \mathrm{ml})$ of the strain of NDV ZG1999HDS or La Sota show in general the priority of the strain of NDV ZG1999HDS. At first, after the TLT cells activation the NO »burst «, $\mathrm{H}_{2} \mathrm{O}_{2}$ and lysozym level increase. After the binding of both NDV viruses separately to the TLT cells and theirs' interaction with the PBMCs, the decrease of GM-CSF and increase of TNF $-\alpha$ and IFN $-\gamma$ was found. Concomitantly, it was found the decrease of pro - inflammatory cytokines (IFN- $\alpha$ ) and the differentially increase of IL-1 $\alpha$, IL-2 and IL-4. During the inducion of the antibacterial response, it was $1 / 3$ higher when it was induced with NDV ZG1999HDS against Gram - positive bacteria (Staphylococcus aureus, MRSA, Streptococcus pyogenes, Streptococcus agalactiae and Streptococcus mutants). Against Gram - negative bacteria (Escherichia coli, Pseudomonas aeruginosa, Proteus mirabilis and Acinetobacter baumanii) this effect was not so clear (Figure 7, Figure 8). One of possible explanation is, in the level of lysozym induced by the strain of NDV ZG1999HDS in comparison to La Sota. Although NDV causes direct oncolytic effects on tumour cells, it has also the ability to modulate the human immune system. So, Wolska et al. [25] showed that cellular cytotoxicity of PBMC was enhanced significantly, after co-incubation of NDV with the effectors cells. Throughout the study, NK cells were found to be the predominant mediator of lyses. Indeed, NDV was found to stimulate the host immunity to produce NO and cytokines, such as IFN- $\alpha$, IFN- $\gamma$, TNF- $\alpha$, and IL-1, which in turn leads to the activation of NK cells, macrophages, and sensitized T cells as it was shown by Avaki et al. [26]. Therefore, the activated NK cells are important contributors to innate defence against viral infections and through the stimulating of cytokines' secretion, such as IL-2, IFN- $\gamma$, and TNF$\alpha$, further influencing and activating other immune cells' functions connected with cytolysis so affecting the tumour cells.

\section{Conclusions}

The immunotherapy raised the attention of many scientists because it holds to promise to be an attractive therapeutic strategy for treating different medical disorders. In this study, the immunomodulatory effects of low titres $(10 \mathrm{HA} / \mathrm{ml})$ of the strain of NDV ZG1999HDS in comparison to La Sota on mixture of TLT cells with PBMC were analyzed. The TLT activation by the $\mathrm{NO} »$ burst «, $\mathrm{H}_{2} \mathrm{O}_{2}$ and lysozym level increase. After the binding to the TLT cells and theirs interaction with the PBMC, the decrease of GM-CSF, and increase of TNF $-\alpha$ and IFN $-\gamma$ was found. Concomitantly, the decrease of pro - inflammatory cytokines (IFN- $\alpha$ ) and the selected increase of IL- $1 \alpha$, IL-2 and IL-4 were found. In inducing of the antibacterial response, it was $1 / 3$ higher, when it was induced with the strain of NDV ZG1999HDS against Gram - positive bacteria (Staphylococcus aureus, MRSA, 
Streptococcus pyogenes, Streptococcus agalactiae and Streptococcus mutants). Against Gram negative bacteria (Escherichia coli, Pseudomonas aeruginosa, Proteus mirabilis and Acinetobacter baumanii) this effect was not so clear. In general, the strain of NDV ZG1999HDS was immunomodulatory stronger than La Sota in vitro.

Authors' Contributions:F.B., L.G. and H.M. prepare and perform the experiments and the text of the article. A.P. performs the RP-HPLC analyses of different samples. L.G. and A.P. made the language of the text. T.V. made the English corrections.

Conflicts of Interest:All the authors have declared that there is no conflict of interest.

Funding:The research was performed in the frame of CIETO (Croatian institute for Experimental and Translational Oncology, Koledinečka 03, 10040 Zagreb, Croatia). It was included into the Project: "Oncolytic Newcastle Disease Virus in the Veterinary Medicine." The research was partially supported by Ivan Čermak and by Crodux - plin, Savska Opatovina, 10000 Zagreb, Croatia.

Acknowledgments:Authors are indebted to Tomaž Velnar for English suggestions .

\section{References}

[1] Ortuño-Sahagún, D., Zänker, Rawat, A.K.S., Kaveri, S.V., Hegde, P. Natural Immunomodulators. J. Immunol Res. 2017. 7529408. DOI: $10.1155 / 2017 / 7529408$

[2] Stanilova, S.A., Dobreva,Z.G., Slavov,E.S., LD. Miteva, L.D. C3 binding glycoprotein from Cuscuta europea induced different cytokine profiles from human PBMC compared to other plant and bacterial immunomodulators. Intern Immunopharm. 2005. 5(4): 723 - 734. DOI: 10.1016/j.intimp.2004.12.003.

[3] Utoh-Nedos, A.U., Akah, P.A., Okoye, T.C.,CO. Okoli, C.O. Evaluation of the Toxic Effects of Dihydroartemisinin on the Vital Organs of Wistar Albino Rats. Am Journ of Pharmacol. and Toxicol. 2009. 4(4): $169-173$. DOI: 10.3844/ajptsp.2009.169.173.

[4] Tzianabos, A.O. Polysaccharide immunomodulators as therapeutic agents: Structural aspects and biologic function. Clin Microbiol Reviews 2000. 13(4): 523 - 533 DOI: $10.1128 / \mathrm{cmr} .13 .4 .523-533.2000$.

[5] Ooi, V.E., Liu, F. Immunomodulation and anti-cancer activity of polysaccharide-protein complexes. Current medicinal chemistry. 2000. 7(7): 715 - 729. DOI: $10.2174 / 0929867003374705$.

[6] Kobayashi, S., Sato, R., Aoki, T., Omoe, K., Inanami, O., Hankanga, C., Yamada, Y., Tomizawa, N., Yasuda, Jun. Sasaki, J. Effect of bovine lactoferrin on functions of activated feline peripheral blood mononuclear cells during chronic Feline immunodeficiency virus isolation. J Vet Med Sci. 2008. 70(5): 429 - 435. DOI: $10.1292 /$ jvms. 70.429 .

[7] Schirrmacher, V., Ahlert, T., Probstle, T., Steiner,H.H., C. Herold - Mende, C., Gerhards, R., Hagmuller, E., Steiner, H.H. Immunization with virus-modified tumour cells. Sem Oncol. 1998. 25(6): 677- 696. PMID: 9865682.

[8] Schirrmacher, V., Hass, C., Bonifer, R., Ahlert, T., Gerhards, R., Ertel, C. Human tuomour cell modification by virus infection: an efficient and safe way to produce cancer vaccine with pleiotropic immune stymulatory properties when using Newcastle disease virus. Gene Ther. 1999. 6 (1): 63 - 73. DOI: 10.1038/sj.gt.3300787. PMID: 10341877

[9] Schirrmacher, V., Bai, L., Umansky, V., Yu, Y., Xing, Z. Qian, Z. Newcastle disease virus activates macrophages for anti - tumour activity. Int. J. Oncology. 2000. 16 (2): 363 - 436. DOI: 10.3892/ijo.16.2.363.

[10] Zorn, U., Dallman, I., Grosse, J., Kirchner, H., Poliwoda, H., J. Atzpodien, J. Induction of cytokines and cytotoxicity against tumour cells by Newcastle disease virus. Cancer Biother. 1994. 9(3), $225-235$. DOI:10.1089/cbr.1994.9.225

[11] Burke, S., Shergold, A., Elder, J.M., Whitworth, J., Cheng, X., Jin, H., Wilkinson, W.R., Harper, J., Carroll, K. D. Oncolytic Newcastle disease virus activation of the innate immune response and priming of antitumor adaptive responses in vitro. Cancer Immunol Immunother. 2020. 69(6): 1015 - 1027. DOI: $10.1007 / \mathrm{s} 00262-020-02495-x$.

[12] Mazija, H., Gottstein, Ž., Ivanković, S., Čović, D. Lentogenic cytolitic strain of the Newcastle 
disease virus isolated in Croatia (In Croatian). In: Balenović M. (Ed) IX ${ }^{\text {th }}$ Poultry days, Proceedings, Poultry Centre Zagreb, 2011. pp. 48-58.

[13] Mazija, H. Pneumotropic lenthogenic strain of Newcastle disease virus ZG1999HDS isolated in Croatia. Republic of Croatia. State intellectual property Office (In Croatian). Patent application 2011. P20100579A.

[14] Nedeljković, G. Genomic characterization and phylogenetic analysis of Newcastle disease virus isolate ZG1999HDS from the outbreak in 1999 in Croatia. Master's of Science, 2011. Master's Programme in Infection Biology, Uppsala University, Sweden.

[15] Collection National de Cultures de Microorganismes (CNCM). Virus NDV (strain ZG1999HDS) was deposited at "Collection Nationale de Cultures de Microorganismes (CNCM)" in Paris, France. Accession No: CNCM I-4811. 2013.

[16] Anonymous. The sequence data were deposited in the Gene Bank under the accession No : NDV_ZG1999HDS.sqn NDV_Zagreb_1999\Concensus KJ670427. 2015.

[17] Biđin, M., H. Mazija, H. Immunogenicity of field strain of Newcastle disease Virus ZG2000 applied to SPF chickens. VIII th Symposium Poultry days 2009, Croatia, Poreč, March 25 - 28, 2009. pp 241-245 (In Croatian).

[18] Ginting, E.T., Christian, S., Larasati, Y.O., Suryatenggara, J., Suriaparanta, I.M., Mathew, G. Antiviral Interferon's induced by Newcastle Disease Virus (NDV) drive a tumour selective apoptosis. Scientific Reports. 2019. $9: 15160$.

DOI: $10.1038 / S 41598-019-51465-6$.

[19] Antonelli, G. Biological basis for a proper clinical application of alpha interferons. NewMicrobiologica. 2008. 31(3): 305-318. PMID: 18843884.

[20] Orsi, R.O., Funari, S.R.C., Soares, A.M.V.C., Calvi, S.A., Olivera, S.L., Sforcin, J.M., Bankova, V. Immunomodulatory action of propolis on macrophage propolis on macrophage activation. J. Venom. Anim. Toxins. 2000. 6(2): 205 - 219.

DOI: 10.1590/S0104-79302000000200006.

[21] Nash, A.J., Ballard, S.N.T., Weavwer,T.E., Akinbi, T.H. The Peptydoglycan Degrading property of Lysozyme is not Required for Bactericidal activity in vivo. The Journal of Immunology 2006. 177(1): 519 - 526.

DOI: 10.4049/jimmunol.177.1.519.

[22] More, P., Pai, K. Immunomodulatory effects of Tinospora cordifolia (Guduchi) on Immunomodulatory effects of Tinospora cordifolia (Guduchi) on Macrophage activation. Biology and Medicine, 2011.3 (2) Special Issue: 134 - 140, eISSN: 09748369.

[23] Punainen, S., Veripavel, U.R., Tőlö, H., J. Parkkinen, J. Alpha Interferon Manufacturing process Using immunoadsorbtion and virus removal filtration. 1999. Patent No. WO 99/64440.

[24] Lino, A., Deogracious, O. The in vitro antibacterial activity of Annona negalensis, Securidacca longipendiculata and Steganotaenia araliacea - Ugandan medicinal plants. African health sciences. 2006. 6(1): 31 - 35.

DOI: 10.5555/afhs.2006.6.1.31

[25] Wolska, K., Gorska, A., Antosik, K., Lugowska, K. Immunomodulatory Effects of Propolis and its Components on Basic Immune Cell Functions. Indian J Pharm Sci. 2019. 81(4): 575 - 588. DOI: 10.36468/pharmaceutical-sciences.548.

[26] Avaki, S., Turutoglu, H., Simsek, A., Unsal, A. Clinical and immunological effects of Newcastle disease virus vaccine on Bovine papillomatosis. Veterinary Immunology and Immunopathology. 2004. 98 (1-2): 9 - 16.

DOI: $10.1016 /$ j.vetimm.2003.10.003. 